https://doi.org/10.18778/1509-877X.2019.02.01

\title{
KRYTERIUM CELU PONIESIENIA WYDATKU A KOSZTY UZYSKANIA PRZYCHODÓW - TREŚĆ NORMATYWNA I IMPLIKACJE ANTYABUZYWNE (ARTYKUŁ DYSKUSYJNY)
}

\begin{abstract}
Streszczenie. W świetle art. 15 ust. 1 Ustawy z dnia 15 lutego 1992 r. o podatku dochodowym od osób prawnych kosztem uzyskania przychodów może być tylko wydatek (koszt) spełniający przesłankę celu w ujęciu subiektywnym: taki, że osiągnięcie przychodów podatkowych lub zachowanie albo zabezpieczenie jego źródła było samoistnym (nieinstrumentalnym) celem podatnika, który wydatek (koszt) ten poniósł. Warunek ten nie jest spełniony w przypadku wydatków (kosztów) dokonanych w celu poniesienia straty podatkowej. W konsekwencji zastosowanie przepisu polegające na odmowie uznania wydatku (kosztu) za koszt uzyskania przychodów w niektórych przypadkach może udaremnić podjętą przez podatnika próbę unikania opodatkowania.
\end{abstract}

Słowa kluczowe: koszt podatkowy, koszt uzyskania przychodów, unikanie opodatkowania, art. 15 ust. 1 Ustawy z dnia 15 lutego 1992 r. o podatku dochodowym od osób prawnych

\section{WPROWADZENIE}

Celem artykułu jest przedstawienie treści ogólnej klauzuli kosztowej zawartej w art. 15 ust. 1 Ustawy z dnia 15 lutego 1992 r. o podatku dochodowym od osób prawnych ${ }^{1}$ w kontekście możliwości jej zastosowania do

* Doktor habilitowana nauk prawnych, Wydział Prawa Uniwersytetu w Białymstoku, e-mail: hannapatrycja@wp.pl

1 Tekst jedn. Dz.U. z 2019 r., poz. 865 ze zm., dalej: u.p.d.o.p. Odpowiednikiem tego przepisu jest art. 22 ust. 1 Ustawy z dnia 26 lipca 1991 r. o podatku dochodowym od osób 
czynności podatników stanowiących unikanie opodatkowania (czynności abuzywnych). W analizie rozważam możliwość rozumienia kryterium celu poniesienia wydatku (kosztu), na którym zbudowany jest ten przepis, jako definicyjnego dla wymaganego związku między kosztami uzyskania przychodów a przychodami podatkowymi oraz przede wszystkim subiektywnego - dotyczącego sfery motywacyjnej podatnika.

Problem ten - i powiązane $\mathrm{z}$ nim zjawisko wykorzystywania przez organy podatkowe art. 15 ust. 1 u.p.d.o.p. w funkcji klauzuli przeciwko unikaniu opodatkowania - były ostatnio przedmiotem licznych publikacji naukowców i praktyków (B. Brzezińskiego ${ }^{2}$, W. Nykiela i M. Wilka ${ }^{3}$, K. Gila i J. Zawiejskiej-Rataj ${ }^{4}$, M. Kondeja ${ }^{5}$ ). Podpisuję się pod większością tez zawartych w tych publikacjach, w tym pod podstawową $\mathrm{z}$ nich: że art. 15 ust. 1 u.p.d.o.p. nie jest klauzulą przeciwko unikaniu opodatkowania. Przepis ten ma inną treść normatywną w szczególności od klauzuli ogólnej przeciwko unikaniu opodatkowania (art. 119a i n. ustawy Ordynacja podatkowa ${ }^{6}$ ), wprowadzonej z dniem 15 lipca 2016 r. (dalej: GAAR), a w związku $\mathrm{z}$ tym inne od niej warunki stosowania. Zgadzam się również, że argumentacja przedstawiona przez sądy administracyjne w dwóch wyrokach (tj. w wyroku Wojewódzkiego Sądu Administracyjnego (WSA) w Lublinie z dnia 20 marca 2019 r., sygn. I SA/Lu 48/19, uchylonym wyrokiem Naczelnego Sądu Administracyjnego (NSA) z dnia 4 marca 2020 r., sygn. II FSK 1550/19, oraz wyroku WSA w Opolu z dnia 19 sierpnia 2019 r., sygn. I SA/Op 86/19), które przełamały dotychczasową linię orzeczniczą

fizycznych (tekst jedn. Dz.U. z 2019 r., poz. 1387 ze zm.). Dla uproszczenia w tekście głównym odnoszę się tylko do art. 15 ust. 1 u.p.d.o.p.

2 B. Brzeziński, Wyrok Wojewódzkiego Sądu Administracyjnego w Lublinie z dnia 22 stycznia 2019 r. (I SA/Lu 48/19) - glosa, „Przegląd Orzecznictwa Podatkowego” 2019, nr 4, s. 255-259.

${ }^{3}$ W. Nykiel, M. Wilk, Niedopuszczalność wykorzystania art. 15 ust. 1 u.p.d.o.p. jako klauzuli przeciwko unikaniu opodatkowania. Glosa do wyroku WSA z dnia 19 sierpnia 2019 r., I SA/Op 86/19, „Przegląd Podatkowy” 2020, nr 2, s. 39-46.

${ }^{4}$ K. Gil, J. Zawiejska-Rataj, Próba wskrzeszenia klauzuli obejścia prawa podatkowego - czyli czy art. 15 ust. 1 PDOPrU pozwala na wyłaczenie z kosztów podatkowych wydatków wynikających z czynności dokonanych w celu uzyskania korzyści podatkowej. Glosa do wyroków WSA w Opolu I SA/OP 86/19 oraz WSA w Lublinie I SA/Lu 48/19, „Monitor Podatkowy" 2020, nr 3, s. 43 i n., Legalis/el.

${ }_{5}$ M. Kondej, Ustawowa definicja kosztu uzyskania przychodu jako quasi-klauzula przeciwko unikaniu opodatkowania, „Monitor Podatkowy” 2019, nr 8, Legalis/el.

${ }^{6}$ Ustawa z dnia 29 sierpnia 1997 r. - Ordynacja podatkowa (tekst jedn. Dz.U. z 2019 r., poz. 900 ze zm.), dalej: o.p. 
i sprowokowały te publikacje, jest nietrafna, i to nietrafna w sposób charakterystyczny. Wojewódzkie sądy administracyjne potraktowały art. 15 ust. 1 u.p.d.o.p. tak, jakby przepis ten był klauzulą antyabuzywną (zarówno co do hipotezy, jak i sankcji, tj. zarówno co do warunków stosowania, jak i konsekwencji prawnych tego stosowania). To wzbudziło słuszną krytykę (detaliczną zwłaszcza w artykule K. Gila i J. Zawiejskiej-Rataj; ten sam artykuł zawiera wartościowy przegląd orzecznictwa sądowego dotyczącego pozanormatywnych metod zwalczania unikania opodatkowania, stosowanych przez organy podatkowe przed wejściem w życie GAAR).

Mimo to uważam, że w ograniczonym zakresie art. 15 ust. 1 u.p.d.o.p. może być stosowany wobec czynności stanowiących unikanie opodatkowania (czynności abuzywnych) w ten sposób, że odmawia się podatnikowi prawa do zaliczenia wydatków do kosztów uzyskania przychodów. Jest to możliwe na podstawie wpisanej w treść przepisu explicite przesłanki celu poniesienia wydatku (kosztu).

W niniejszej analizie pomijam możliwość stosowania art. 15 ust. 1 u.p.d.o.p. do zwalczania unikania opodatkowania na takiej zasadzie, na jakiej tak stosowany może być każdy przepis materialnego prawa podatkowego (zatem także i ten). Uznając, że unikanie opodatkowania, równoważne nadużyciu materialnego prawa podatkowego, polega na działaniu zgodnym z brzmieniem przepisu, lecz niezgodnym z jego wykładnią racjonalizującą ( $\mathrm{tj}$. wszechstronną wykładnią zorientowaną na uczynienie przepisu w maksymalnym dostępnym stopniu racjonalnym), zjawisko to można zwalczać środkami wykładni ${ }^{7}$. Postulat wykładni racjonalizującej nie należy jednak do aktualnego polskiego paradygmatu interpretacyjnego - do jego stosowania byłaby wymagana zmiana tego paradygmatu, która jednak ze względu na pewność prawa nie powinna być nagła i dla podatników niespodziewana. Co także ważne, sposób zastosowania art. 15 ust. 1 u.p.d.o.p. w krytykowanych wyrokach jest inny od tego, który dyktuje wykładnia racjonalizująca. W sytuacji, do której odnoszą się te wyroki, podatnicy nadużyli nie art. 15 ust. 1 u.p.d.o.p., ale przepisy zapewniające neutralność wniesienia wkładu niepieniężnego w postaci znaku towarowego do podmiotu powiązanego przy jednoczesnym podwyższeniu wartości podatkowej przedmiotu wkładu, rozliczanej następnie przez odpisy amortyzacyjne (zgadzam się w tej mierze z poglądem m.in. K. Gila i J. Zawiejskiej-Rataj) ${ }^{8}$.

7 W sprawie tej wykładni zob. H. Filipczyk, Tax Avoidance and Rationality of Law, Warszawa 2017, rozdziały IV i V.

8 „[O]rgany podatkowe i sądy w analizowanych sprawach niewłaściwie zidentyfikowały korzyść podatkową, do której uwzględniania w wyniku podatkowym nie uprawniły 


\section{NIEZALEŻNOŚĆ I NIEKONKURENCYJNOŚĆ REGULACJI}

Wypada rozpocząć od tego, co - również w świetle powołanych wyżej artykułów w prasie naukowej i specjalistycznej - oczywiste: art. 15 ust. 1 u.p.d.o.p. oraz art. 119a o.p. (a także inne, szczególne przepisy antyabuzywne) stanowią regulacje niezależne.

Ustalając treść normatywną art. 15 ust. 1 u.p.d.o.p., nie należy się kierować treścią ogólnej i szczególnych klauzul antyabuzywnych. Dla zastosowania tego przepisu nie ma znaczenia spełnienie przesłanek, na których opiera się ustawowa definicja unikania opodatkowania: wystąpienie korzyści podatkowej sprzecznej z przedmiotem lub celem ustawy podatkowej lub jej przepisu (kryterium sprzeczności), osiągnięcie tej korzyści jako główny lub jeden z głównych celów dokonania czynności (kryterium głównego celu), sztuczny sposób działania (kryterium sztuczności). Powoływanie się na te przesłanki w celu uzasadnienia zastosowania $\mathrm{w}$ sprawie art. 15 ust. 1 u.p.d.o.p. jest rażącym błędem, słusznie wytykanym organom podatkowym w orzecznictwie 9 .

Niezależność ta ma jednak również stronę (aspekt) rzadziej być może dostrzegany - jakim jest brak wpływu obowiązywania art. 119a o.p. na treść normatywną art. 15 ust. 1 u.p.d.o.p. i na możliwość zastosowania tego przepisu. Ogólna klauzula kosztowa określa warunki zaliczenia wydatku (kosztu) do kosztów uzyskania przychodów w sposób niezależny od GAAR także w tym sensie, że wprowadzenie GAAR nic w tych warunkach nie zmienia. Jeżeli przed wejściem w życie art. 119a i n. o.p. nie było możliwe kwestionowanie kosztowości określonego wydatku na podstawie art. 15 ust. 1 u.p.d.o.p., to po wprowadzeniu GAAR nadal nie jest możliwe, jeżeli było możliwe - nadal jest możliwe.

podatników. W obu sprawach jedyną korzyścią podatkową był brak obowiązku rozpoznania przychodu z tytułu zbycia praw ochronnych do znaków towarowych na rzecz podmiotu powiązanego przy jednoczesnym uprawnieniu do uwzględniania w kosztach podatkowych następczych kosztów nabycia tego znaku (poprzez odpisy amortyzacyjne). To ten element doprowadził do braku symetrii w rozpoznawaniu przychodów i kosztów podatkowych $\mathrm{z}$ danej transakcji. Irrelewantne były tu następcze czynności uiszczania opłat licencyjnych, które były przecież rozpoznawane jako przychód u licencjodawcy" (K. Gil, J. Zawiejska-Rataj, Próba wskrzeszenia..., s. 48).

9 Trafnie także zwraca uwagę B. Brzeziński, że wprowadzenie GAAR nie jest „ogólnym przyzwoleniem, zielonym światłem dla zwalczania unikania opodatkowania także w tym zakresie, którego nie obejmowała nie tylko nieistniejąca dotąd klauzula ogólna, ale także inne środki zwalczania unikania opodatkowania (np. klauzule szczegółowe)” (B. Brzeziński, Wyrok..., s. 555). To kolejny aspekt niezależności wskazanych regulacji. 
Pogląd ten może wydawać się wątpliwy w świetle systemowości prawa. Stoi za nim jednak charakter oraz zamierzony zakres i sposób stosowania GAAR. Przepisy GAAR, ze względu na znaczną ingerencyjność i łączące się z nią rygorystyczne proceduralne warunki ich stosowania, stanowią regulację „ostatniej szansy”, czy też „zastosowania w ostatniej kolejności” (last resort). Mają być albo są stosowane w ostatniej kolejności, gdy nieadekwatne, w tym niewystarczające do zwalczania unikania opodatkowania, okazują się przepisy zawarte w poszczególnych ustawach podatkowych. Odzwierciedleniem tego „porządku stosowania” była w stanie prawnym przed 1 stycznia 2019 r. treść art. 119b $\$ 1$ pkt 5 o.p. Zgodnie z przepisem w ówczesnym brzmieniu art. 119a nie stosuje się, ,jeżeli zastosowanie innych przepisów prawa podatkowego pozwala na przeciwdziałanie unikaniu opodatkowania”. Wraz z uchyleniem tego przepisu z dniem 1 stycznia 2019 r. wprowadzono do o.p. art. 119gb $\$ 1$. Przepis ten daje Szefowi Krajowej Administracji Skarbowej swobodę decydowania o przejęciu kontroli lub postępowania w celu zastosowania GAAR albo odmowie jego przejęcia - „jeżeli zastosowanie innych niż art. 119a przepisów prawa podatkowego pozwala na przeciwdziałanie unikaniu opodatkowania”.

Niezależnie od kontrowersji otaczających wskazane przepisy przed zmianą, jak i po niej ${ }^{10}$, jedno pozostaje bezsporne: z przepisów nie wynikało i nie wynika, że możliwość zastosowania GAAR w danym stanie faktycznym czyni niedopuszczalnym zastosowanie w nim przepisu prawa materialnego z ustawy szczegółowej, w tym art. 15 ust. 1 u.p.d.o.p. Wręcz przeciwnie, przed nowelizacją ustawodawca wskazywał jako preferowaną regulację, tj. taką, którą należy stosować w pierwszej kolejności, przepisy inne niż GAAR - o ile te pozwalają na skuteczne przeciwdziałanie unikaniu opodatkowania.

Dlatego nie bacząc zarówno - w ujęciu abstrakcyjnym, na obowiązywanie GAAR i - w ujęciu konkretnym, na stosowalność GAAR w stanie faktycznym w danej sprawie, należy koncentrować się wyłącznie na ustawowych przesłankach zawartych w art. 15 ust. 1 u.p.d.o.p. - na ich podstawie oceniać zasadność stosowania tego przepisu. To, że do danego stanu faktycznego może mieć potencjalnie zastosowanie GAAR, nie wyłącza

${ }_{10}$ Na temat relacji klauzuli ogólnej do przepisów szczególnych zob. zwłaszcza H. Litwińczuk, Regulacje o cenach transferowych a ogólna norma przeciwko unikaniu opodatkowania, „Przegląd Podatkowy” 2018, nr 10, s. 18-23, i powołana tam literatura; P. Karwat, Klauzula ogólna a przepisy szczególne przeciwdziałające unikaniu opodatkowania, „Przegląd Podatkowy” 2016, nr 12, s. 12-20. 
możliwości zastosowania do niego art. 15 ust. 1 u.p.d.o.p. Także to, że do danego stanu faktycznego mógłby mieć zastosowanie GAAR (gdyby nie to, że wszedł w życie później), możliwości takiej nie wyłącza.

\section{KRYTERIUM CELU W ART. 15 UST. 1 U.P.D.O.P. - ASPEKT SUBIEKTYWNY}

Zgodnie $\mathrm{z}$ art. 15 ust. 1 u.p.d.o.p. kosztami uzyskania przychodów są koszty poniesione w celu osiągnięcia przychodów ze źródła przychodów lub w celu zachowania albo zabezpieczenia źródła przychodów, z wyjątkiem kosztów wymienionych $\mathrm{w}$ art. 16 ust. 1 u.p.d.o.p. W stanie prawnym przed 1 stycznia 2018 r. przepis nie zawierał odniesienia do źródła przychodów; z tą datą wprowadzono podział przychodów (dochodów) objętych zakresem przedmiotowym ustawy na dwa źródła.

$\mathrm{Z}$ art. 15 ust. 1 u.p.d.o.p. wynika normatywne pojęcie kosztów uzyskania przychodów. Pojęcie to jest kształtowane znanymi warunkami zaliczalności wydatku do kosztów podatkowych. W obecnym kontekście najważniejszy $\mathrm{z}$ nich to warunek poniesienia wydatku „w celu osiągnięcia przychodów lub zachowania albo zabezpieczenia źródła przychodów" (w dalszej części tekstu dla uproszczenia posługuję się w jego zastępstwie skrótowymi określeniami „kryterium celu” i „cel uzyskania przychodu podatkowego").

W doktrynie mowa zwykle o subiektywno-obiektywnym charakterze tego kryterium. Przykładowo W. Nykiel i M. Wilk (z powołaniem na dalszą literaturę) wskazują, że „konstrukcja przesłanki poniesienia kosztu w celu osiągnięcia przychodów ma charakter dwuczłonowy - subiektywno-obiektywny. Należy przyjąć, że koszt jest poniesiony w celu osiągnięcia przychodów, jeżeli: 1) podatnik działał z zamiarem osiągnięcia przychodów (kryterium subiektywne) oraz 2) doświadczenie gospodarcze wskazuje, że koszt ten może - choćby potencjalnie i pośrednio - prowadzić do osiągnięcia przychodów (kryterium obiektywne)"11. Przedmiotem licznych wypowiedzi doktryny i orzecznictwa jest „obiektywny” aspekt kryterium - to głównie w nim sytuowana jest wątpliwość interpretacyjna co do właściwego rozumienia tego kryterium ${ }^{12}$. W tym kontekście wskazuje się m.in. na niewystarczalność spełnienia subiektywnej „części” kryterium, wywa-

11 W. Nykiel, M. Wilk, Niedopuszczalność..., s. 41.

12 Zob. np. K. Gil, Zasada ponoszenia kosztów w celu uzyskania przychodów w świetle reguł wykładni przepisów prawa podatkowego, „Monitor Podatkowy” 2010, nr 7, Legalis/el. 
ża (w różny sposób) udział komponentów subiektywnego i obiektywnego, a także poszukuje czynników obiektywizujących związek kosztu z przychodem (przychodami). Dociekania na ten temat prowadzą np. M. Kondej (który wskazuje, że spełnienie tego kryterium należy oceniać przez odniesienie do figury „rozsądnego podatnika” i do wymogów należytej staranności ${ }^{13}$ ) czy P. Borszowski (który postuluje odniesienie do „typowego” zachowania podmiotu w realiach rynkowych ${ }^{14}$ ).

Tymczasem również aspekt subiektywny kryterium celu skrywa głębię - ponieważ dopuszcza różne warianty interpretacyjne. Kryterium celu w aspekcie subiektywnym ma podwójne oblicze. $\mathrm{Z}$ jednej strony jego zastosowanie przez ustawodawcę uprawnia do zaliczenia do kosztów uzyskania przychodów wydatków, które mimo jego spełnienia nie doprowadziły do osiągnięcia przychodów. Jak celnie zauważa A. Gomułowicz (w analizie językowej najbardziej chyba wnikliwej z dostępnych), zgodnie z formułą osiągnięcie przychodu podatkowego ma być „celem”, a nie (niekoniecznie) „skutkiem” poniesienia wydatku ${ }^{15}$. Z drugiej strony natomiast - można argumentować, że kryterium celu dyskwalifikuje wydatki, których poniesienie nie miało na celu osiągnięcia przychodów.

Zgodnie z tą argumentacją strona subiektywna kryterium celu wymaga, by wydatek został poniesiony w celu uzyskania przychodu podatkowego - niezależnie od tego, czy przychód rzeczywiście wystąpił. Na spełnienie tego kryterium nie ma więc wpływu nie tylko nieosiągnięcie przychodu, ale także jego osiągnięcie. W świetle samego brzmienia formuły z art. 15 ust. 1 u.p.d.o.p. wystąpienie przychodu podatkowego jest nie tylko niekoniecznym, ale i niewystarczającym warunkiem dokonania takiego zaliczenia.

Wobec powyższych uwag doprecyzowania i uzupełnienia wymaga stwierdzenie, że badając spełnienie przez wydatek warunków wynikających $\mathrm{z}$ art. 15 ust. 1 u.p.d.o.p., nie należy brać pod uwagę celu w postaci korzyści podatkowej. To prawda, że korzyść podatkowa jako taka, ani dążenie do

${ }^{13}$ M. Kondej, Jeszcze o koszcie jako wydatku związanym z przychodami. Racjonalność działania podatnika jako przesłanka rozpoznania kosztu podatkowego, „Kwartalnik Prawa Podatkowego" 2018, nr 4, s. 93-109.

${ }_{14}$ P. Borszowski, Normatywne określenie „kosztów podatkowych z działalności gospodarczej" - zagadnienie elastyczności, [w:] Finanse publiczne i prawo finansowe - realia i perspektywy zmian, red. L. Etel, M. Tyniewicki, Białystok 2012, s. 362-363.

15 A. Gomułowicz, Prawna formuła kosztu podatkowego, Warszawa 2016, rozdział I.4, LEX/el. Podobnie m.in. wyrok NSA z dnia 27 stycznia 2003 r., sygn. III SA 1652/01. Zob. także B. Gruszczyński, Cel osiagnięcia przychodów, „Glosa” 2003, nr 2, s. 9-16. 
niej, nie dyskwalifikuje wydatku z punktu widzenia rozpatrywanego przepisu. Dyskwalifikuje go natomiast brak spełnienia warunku celu - celem tym powinno być osiągnięcie przychodów podatkowych. W niektórych przypadkach (do których - dodajmy - nie należą te będące przedmiotem orzekania przez WSA w Opolu i WSA w Lublinie) poniesienie wydatku ma za cel osiągnięcie korzyści podatkowej, a nie uzyskanie przychodów podatkowych. Jednocześnie ukierunkowanie wydatku na korzyść podatkową niekoniecznie „wypiera” - równorzędny z nim lub nadrzędny - cel uzyskania przychodów podatkowych.

Do stwierdzenia, czy spełnione jest kryterium celu, potrzebne jest badanie sfery motywacyjnej podatnika. W szczególności badanie to może polegać na ustalaniu relacji między różnorodnymi motywami podatnika przyświecającymi poniesieniu wydatku - relacji między celami gospodarczymi a celami podatkowymi ${ }^{16}$.

Spełnienie kryterium subiektywnego podlega ocenie zobiektywizowanej. Organ podatkowy ocenia je na podstawie całokształtu okoliczności sprawy, a nie opierając się wyłącznie na deklaracji (oświadczeniu) podatnika. Stan psychiczny podatnika (osób go zastępujących) trzeba ustalać, opierając się na jego zachowaniach, tj. aktach uzewnętrznionych, dostępnych obserwacji przez inne podmioty. Organ podatkowy jest kompetentny do dokonywania takich ocen, ponieważ jest kompetentny do stosowania art. 15 ust. 1 u.p.d.o.p., a przepis ten zawiera i wyraża kryterium celu. Jeżeli oświadczenie podatnika jest pozbawione wiarygodności, organ może - posługując się odpowiednią argumentacją oraz w granicach i na zasadach swobodnej oceny dowodów - na podstawie ustalonych okoliczności danego przypadku odmówić temu oświadczeniu wiary. Obiektywizacja kryterium celu nie dotyczy zatem tylko jego aspektu obiektywnego, ale także subiektywnego („subiektywny” znaczy w tym przypadku „dotyczący podmiotu”, a nie „zsubiektywizowany, podlegający ocenie subiektywnej") ${ }^{17}$.

${ }^{16}$ Przeciwnie W. Nykiel, M. Wilk, Niedopuszczalność..., s. 44.

17 Nie ma przy tym normatywnych podstaw do nakładania na podatnika tzw. „ciężaru dowodu”, że kryterium celu poniesienia wydatku zostało spełnione. Podzielam w tej mierze dominujący pogląd doktryny - zob. np. B. Brzeziński, Wyrok..., s. 257. 
Sfera motywacyjna podatnika może być bogata w różnorodne, jednocześnie występujące motywy. Cel czy zamiar osiągnięcia przychodów, jako motyw poniesienia wydatku, może współistnieć z innymi celami, zamiarami i motywami. Układ motywów powinien pozostawać bez wpływu na kosztowość wydatku, nawet jeżeli do motywów tych należy korzyść podatkowa $^{18}$ - pod warunkiem że jednym $\mathrm{z}$ nich jest rzeczywiście cel (zamiar, motyw) osiągnięcia przychodów podatkowych.

Przepis art. 15 ust. 1 u.p.d.o.p. nie wymaga, by cel uzyskania przychodów był celem jedynym. Powinien to być cel samoistny (w odróżnieniu od instrumentalnego). Najogólniej rzecz ujmując, cel samoistny to to, do czego podatnik dąży ze względu na nie samo. Cel instrumentalny to to, do czego podatnik dąży ze względu na co innego ${ }^{19}$. Tylko taka wykładnia pozwala, jak się wydaje, na nadanie kryterium celu odpowiedniej wagi - czego wymaga fakt, że to na tym kryterium ustawodawca oparł art. 15 ust. 1 u.p.d.o.p.

Cel uzyskania przychodów podatkowych nie może być jedynie celem instrumentalnym, służebnym względem nadrzędnego celu osiągnięcia korzyści podatkowej. W takim przypadku rzeczywiście cel osiągnięcia korzyści podatkowej niweczy wystąpienie celu osiągnięcia przychodów podatkowych - nie może z nim współistnieć w sposób uzasadniający zaliczenie wydatku (kosztu) do kosztów uzyskania przychodów. W konsekwencji czynności abuzywne - działania stanowiące unikanie opodatkowania, które odpowiadają powyższej charakterystyce, mogą spotkać się z reakcją polegającą na zastosowaniu art. 15 ust. 1 u.p.d.o.p. przez odmowę uznania wydatku (kosztu) za koszt podatkowy. Dotyczy to w szczególności czynności polegającej na poniesieniu wydatku w celu poniesienia straty podatkowej (zob. także dalsze rozważania).

Poważne (i zgodne z postulowanym wyżej) rozumienie kryterium celu uwidacznia się na polu innym niż unikanie opodatkowania w odniesieniu do wydatków ponoszonych przez przedsiębiorców w celach przede wszystkim prywatnych. Wydatki te pośrednio mogą się przyczynić do

${ }^{18}$ W tym zakresie należy się zgodzić, że „nawet gdyby okazało się, że jednym z motywów działania podatnika (bądź podmiotów z nim powiązanych), które doprowadziły do poniesienia danego wydatku, było osiągnięcie korzyści podatkowej, to fakt ten pozostaje bez znaczenia prawnego dla oceny, czy wydatek ten stanowi koszt uzyskania przychodów" (W. Nykiel, M. Wilk, Niedopuszczalność..., s. 42).

19 Por. np. Arystoteles, Etyka nikomachejska, przeł. D. Gromska, Warszawa 2007, ks. I. 
uzyskiwania przychodów podatkowych (choćby przez poprawę samopoczucia podatnika, który dzięki temu z większym zaangażowaniem i skuteczniej prowadzi swoje sprawy gospodarcze). Można byłoby więc argumentować, że towarzyszy im intencja uzyskania przychodów podatkowych - choć jest ona odległa, uboczna, drugorzędna. W powszechnym odbiorze dyskwalifikuje je (jako możliwe koszty uzyskania przychodów) jednak to, że pierwszorzędnym ich celem jest interes własny ponoszącego, wiązany z jego sferą prywatną; interes jego działalności gospodarczej nie jest równie ważny.

Nie uchodzi uwadze pewne podobieństwo zaproponowanej wyżej formuły do jednej z przesłanek GAAR (art. 119a $\$ 1$ o.p.), tj. przesłanki „celu głównego lub jednego z głównych”. Nie jest jasne, czy rzeczywiście zachodzi tożsamość między celem głównym a celem samoistnym poniesienia wydatku (względnie czy zdania „X jest celem głównym” i „X jest celem samoistnym” są równoważne). Nawet zakładając taką tożsamość i równoważność, jest to podobieństwo à rebours. W przypadku klauzuli orientacja działania na osiągnięcie korzyści podatkowej sprzecznej z celem lub przedmiotem ustawy podatkowej lub jej przepisu jest kryterium podmiotowym unikania opodatkowania. Natomiast w przypadku art. 15 ust. 1 u.p.d.o.p. orientacja na uzyskanie przychodu podatkowego uprawnia podatnika do zaliczenia wydatków do kosztów uzyskania przychodów - nawet jeżeli motyw ich osiągnięcia jest tylko „jednym z głównych” (czy raczej „jednym z samoistnych”). To, co tam budzi zastrzeżenia jako kryterium zbyt rozległe (przynajmniej przy literalnym odczytaniu), tu podobnych zastrzeżeń nie budzi - sprzyja uznaniu wydatku za koszt podatkowy.

5. WYDATEK W CELU PONIESIENIA STRATY PODATKOWEJ; RACJONALNOŚĆ EKONOMICZNA

Z punktu widzenia analizowanego przepisu nie ma prawnego znaczenia racjonalność ekonomiczna (gospodarcza) działań podatnika. W konsekwencji badaniu przez organy podatkowe nie podlega efektywność gospodarcza działań rozumiana jako parametr optymalnego wyboru środków do realizacji przyjętego celu (tu: osiągnięcia przychodów). Organy podatkowe nie są uprawnione do weryfikacji, czy opłacalne było „zużycie” kosztów o określonej wartości dla osiągnięcia określonego wolumenu przychodów lub czy dany koszt był dla tego celu niezbędny. Podatnik zalicza wydatek 
(koszt) do kosztów uzyskania przychodów także w przypadku, gdy podjęte działania skazywały go na rozpoznanie straty ${ }^{20}$.

W tym kontekście warto powołać interesujące rozważania M. Kondeja - po to, by zgadzając się z nimi co do założeń (tj. w punkcie wyjścia), na ich drodze zmienić jednak nieco kurs, a w konsekwencji zdystansować się w pewnym stopniu od konkluzji. Autor ten argumentuje, że „[o]dwołanie się w ustawowej definicji do przychodu, a nie dochodu, wyraźnie wskazuje, że to, czy oczekiwanym skutkiem działań podatnika jest dochód czy też strata, nie ma znaczenia dla prawa podatnika do rozpoznania kosztu podatkowego. Gdyby ustawodawca chciał, by jedynie wydatki ekonomicznie racjonalne stanowiły koszty, powinien był w tejże definicji wprowadzić wymóg istnienia związku wydatku z dochodem, a nie przychodem"21. Posługuje się techniką eksperymentu myślowego: rozważa przypadek, w którym podatnik prowadzi działalność, w której z założenia (w sposób zamierzony) koszty nie znajdują pokrycia w osiąganych przychodach. Jego zdaniem takie założenie nie uniemożliwia uznania kosztów uzyskania przychodów za spełniające warunki $z$ art. 15 ust. 1 u.p.d.o.p.

Ten frapujący przykład wymaga, moim zdaniem, rozbioru. Dokonywanie przez podatnika wydatków (kosztów) w celu ponoszenia strat (bo do tego, jak się zdaje, sprowadza się sytuacja stanowiąca kanwę eksperymentu myślowego) byłoby zachowaniem ekscentrycznym. Dla eksperymentu myślowego można jednak dopuścić zajście takiej sytuacji. Wtedy z kolei trudno sobie wyobrazić wspólistnienie celów: osiągnięcia przychodów podatkowych i poniesienia straty ekonomicznej (jako celów nie tylko deklarowanych, ale i realnych). Jeżeli jednak rzeczywiście okoliczności danej sprawy uzasadniają pogląd, że cele takie towarzyszyły podatnikowi ponoszącemu wydatek (koszt), koszt ten podlega zaliczeniu do kosztów uzyskania przychodów.

W rzeczywistości gospodarczej dużo częstszy jest jednak przypadek dający się opisać nieco inaczej - taki, że podatnik z założenia zmierza do poniesienia straty podatkowej (nie zaś straty tout court, rozumianej jako strata ekonomiczna). Współistnienie w takim przypadku celu poniesienia

${ }^{20}$ H. Filipczyk, Jeszcze raz o kosztach uzyskania przychodów - cztery mity, „Prawo i Podatki” 2009, nr 12, s. 11. Por. A. Gomułowicz, Prawna..., rozdział I.4. „Cel a następstwo - istota sporu".

${ }^{21}$ M. Kondej, Jeszcze o koszcie..., s. 99. Podobnie m.in. J. Bołd, Komentarz do art. 15, [w:] Podatek dochodowy od osób prawnych. Komentarz, red. K. Gil, A. Obońska, A. Wacławczyk, A. Walter, wyd. 3, Warszawa 2020. 
straty podatkowej oraz celu osiągnięcia przychodów podatkowych jako samoistnych, jakkolwiek a priori nadal możliwe (dające się pomyśleć), jest niezwykle mało prawdopodobne. Doświadczenie życiowe uczy, że jeżeli podatnik ma na celu osiągnięcie przychodu podatkowego $\mathrm{w}$ takim przypadku, to tylko jako służebnego wobec głównego celu, jakim jest poniesienie straty podatkowej. Przychód podatkowy ma zabezpieczyć jego pozycję w razie sporu z organami podatkowymi. Orientacja na stratę podatkową pragmatycznie wyklucza się z orientacją na przychód podatkowy - jeżeli oba te cele miałyby być samoistnymi. W konsekwencji organy podatkowe w takim przypadku słusznie mogłyby stwierdzić, że podatnik nie jest uprawniony do zaliczenia wydatku (kosztu) do kosztów uzyskania przychodów.

6. Kryterium CELU a ZWiąZeK WydatKu (Kosztu) Z PRZYCHODAMI PODATKOWYMI I Z DZIAŁALNOŚCIĄ GOSPODARCZĄ (WYKŁADNIA JĘZYKOWA)

Powyższy pogląd znajduje, moim zdaniem, oparcie w brzmieniu art. 15 ust. 1 u.p.d.o.p. Na tej konstatacji nie można jednak poprzestać. Analiza treści normatywnej tego przepisu nie może pomijać znaczeń języka prawnego, ukształtowanych w doktrynie i orzecznictwie. Także te znaczenia i namysł nad nimi należą do szeroko pojętej wykładni językowej przepisu - który nie powinien być poddawany wyłącznie interpretacji „surowej”, niezapośredniczonej w tradycji jego rozumienia przez poprzedników.

Badanie dotychczasowych wypowiedzi doktryny i orzecznictwa na ten temat ukazuje dwa elementy potencjalnie stwarzające kłopot dla proponowanego rozumienia kryterium celu. Przede wszystkim kryterium celu jest zwykle, jak się wydaje, explicite lub (częściej) implicite rozumiane jako jednostronne (asymetryczne). Wyrażenie ustawowe, użyte $\mathrm{w}$ art. 15 ust. 1 u.p.d.o.p., jest rozumiane jako zapewniające zaliczenie do kosztów uzyskania przychodów wydatku (kosztu), który mimo poniesienia w celu uzyskania przychodów, przychodów takich nie przyniósł (nie przyczynił się do ich uzyskania ani do zachowania lub zabezpieczenia ich źródła). Rekonstruując ten pogląd, należy przyjąć, że kryterium celu ma być „czynne” tylko w przypadku, gdy rozpatrywany wydatek nie przyniósł przychodu podatkowego. W przypadku natomiast, gdy wydatek daje się (przy pomocy innego kryterium) powiązać z przychodem podatkowym, kryterium celu jest bez znaczenia. Kryterium pozwala na „abstrahowanie 
od skutku”22 poniesienia wydatku (kosztu), czy też uznawanie za koszt podatkowy wszelkich wydatków, które mają „potencjał przyczynienia się do osiągnięcia przychodów”23 (zrealizowany bądź nie). Wyrazem tego poglą$\mathrm{du}$ jest formuła znana $\mathrm{z}$ orzecznictwa sądowego, zgodnie $\mathrm{z}$ którą kosztem uzyskania przychodów jest taki, którego poniesienie „ma lub mogło mieć wpływ" na uzyskanie przychodów podatkowych (w tym zachowanie lub zabezpieczenie źródła przychodów) ${ }^{24}$. W niektórych orzeczeniach sądowych wprost uznaje się za zbędne deliberacje na temat spełnienia kryterium celu w sytuacji, gdy związek między przychodem podatkowym a kosztem jego uzyskania jest oczywisty (ustalony na podstawie związku przyczynowego między poniesieniem kosztu a osiągnięciem przychodu $)^{25}$.

$\mathrm{Z}$ drugiej strony w niektórych wypowiedziach przedstawiciele doktryny akcentują mocno cel poniesienia wydatku, jako warunek sine qua non jego kosztowości oraz jako warunek definicyjny dla prawnego pojęcia kosztu uzyskania przychodów. Wskazują na przykład, że:

- „[p]osługując się terminologią teorii prawa karnego, [...] po stronie podatnika musi zachodzić zamiar bezpośredni kierunkowy (dolus directus coloratus)" [osiągnięcia przychodów]"26;

- „[w]ydatek ujęty w kosztach podatkowych powinien być dokonany w celu uzyskania przychodów, a nie w innym"27;

- „[s]formułowanie «koszty poniesione w celu osiągnięcia przychodów» odnosi się przede wszystkim do cech działania, jakim jest poniesienie kosztu, i analiza konkretnego przypadku powinna polegać na badaniu tych okoliczności, a nie powiązania między kosztem a przychodem. Kwalifikowanie określonych kosztów jako kosztów uzyskania przychodów wymaga zatem odtworzenia i oceny motywacji (przesłanek decyzji) podatnika ponoszącego określone koszty, a ewentualne

${ }^{22}$ M. Wilk, Komentarz do art. 15, [w:] A. Krajewska i in., Podatek dochodowy od osób prawnych. Komentarz, wyd. 4, Warszawa 2016, LEX/el.

23 W. Nykiel, M. Wilk, Niedopuszczalność..., s. 41.

24 Zob. np. wyroki NSA: z dnia 22 października 2019 r., sygn. II FSK 3709/17; z dnia 17 października 2019 r., sygn. II FSK 3570/17. Podobnie m.in. W. Dmoch, Komentarz do art. 15, [w:] idem, Podatek dochodowy od osób prawnych. Komentarz, Warszawa 2020.

25 Zob. wyrok NSA z dnia 6 grudnia 2019 r., sygn. II FSK 2078/19 (w sprawie sporne było uznanie za koszt uzyskania przychodów wydatków na nabycie udziałów, z których zbycia podatnik osiągnął przychód podatkowy).

26 B. Gruszczyński, Cel osiągnięcia..., s. 9.

27 P. Małecki, M. Mazurkiewicz, Komentarz do art. 15, [w:] iidem, CIT. Komentarz. Podatki i rachunkowość, wyd. 10, Warszawa 2019, LEX/el. 
faktyczne wystąpienie przychodu ma w tym zakresie jedynie pomocniczy charakter"28; wreszcie że

- „[i]stotne jest jedynie, aby przekonanie tego właśnie konkretnego podatnika było takie, że przez ponoszenie określonego kosztu dąży on do osiągnięcia, zachowania, zabezpieczenia źródła przychodu”29.

Mimo tych kategorycznych stwierdzeń przypisywanie ich autorom poglądu prezentowanego $\mathrm{w}$ tym artykule byłoby nadużyciem (ich kontekst był inny). Więcej waży fakt, że postulowany sposób myślenia przejawił się w orzecznictwie sądowym, aprobatywnie cytowanym przez kilku autorów. W wyroku WSA w Krakowie z dnia 13 maja 2008 r., sygn. I SA/Kr 1293/07, wskazano, że „[t]ylko, jeżeli w konkretnej sprawie analiza postępowania danej osoby w świetle zasad logiki oraz doświadczenia życiowego prowadziłaby do wniosku o oczywistym oraz zupełnym «braku jakiegokolwiek sensu» podjętych działań, zmierzających zasadniczo nie do chęci rzeczywistego osiągnięcia danego przychodu, ale np. do «sztucznego», wyłącznie dla celów podatkowych, wygenerowania kosztów, można by ewentualnie mówić o braku związku przyczynowo-skutkowego. Wówczas bowiem inny jest zamiar podatnika. Zamiast osiągnięcia przychodu, dąży on wyłącznie np. do uniknięcia zapłaty podatku"30. Jednolitość podejścia, jako możliwy argument przeciwko postulowanemu tu rozumieniu subiektywnej części kryterium celu, być może zatem nie występuje, a dotychczasowy dorobek doktryny i orzecznictwa przynajmniej w części dopuszcza to rozumienie.

Jak zatem odnieść się do sytuacji, gdy podatnik osiąga przychód podatkowy dający się powiązać $\mathrm{z}$ analizowanym wydatkiem (kosztem), który to wydatek (koszt) nie był jednak poniesiony w celu uzyskania przychodów? Odpowiedź na to pytanie zależy od roli, jaką przewidzimy dla kryterium celu. Jeżeli kryterium to potraktujemy jako definicyjne dla wymaganego w art. 15 ust. 1 u.p.d.o.p. związku między kosztem a przychodem, wskazana sytuacja ex definitione nie może się zdarzyć. Nie może być kosztu (wydatku) związanego z przychodem podatkowym (przychodami podatkowymi) w braku spełnienia kryterium celu.

${ }^{28}$ M. Ślifirczyk, Komentarz do art. 15, [w:] G. Dźwigała i in., Ustawa o podatku dochodowym od osób prawnych. Komentarz, wyd. 2, Warszawa 2009, LEX/el.

29 K. Gil, Zasada ponoszenia kosztów..., s. 23.

${ }^{30}$ Zob. ponadto (również „popularny” w komentarzach) wyrok NSA z dnia 23 września 2008 r., sygn. II FSK 867/07: „[n]ie tworzą kosztów działania podejmowane w innym celu niż uzyskanie przychodów”. 
Jeżeli kryterium to uznamy za pomocnicze (używane tylko w razie niespełnienia podstawowego kryterium związku kosztu z przychodem), sytuacja taka może natomiast wystąpić - wydatek (koszt) zostanie uznany za koszt uzyskania przychodów na podstawie kryterium podstawowego. Taka optyka zobowiązuje jednak do wyjaśnienia, jakiego rodzaju związek musi łączyć koszty i przychody - skonstruowania lub wskazania tego kryterium pierwszego rzędu.

Próby wskazania i objaśnienia tego kryterium podejmowano w doktrynie, często związek między przychodami podatkowymi a kosztami ich uzyskania opisując w opozycji do cywilistycznej koncepcji związku przyczynowo-skutkowego (przyczynowego) ${ }^{31}$. Z tym zagadnieniem wiąże się drugi element dotychczasowej refleksji doktrynalnej rzucający światło na rozpatrywany problem treści normatywnej art. 15 ust. 1 u.p.d.o.p. Charakterystyczny jest mianowicie przekład doktrynalny wyrażenia ustawowego „koszty poniesione w celu uzyskania przychodów” na „koszty ponoszone $\mathrm{w}$ interesie przedsiębiorstwa” lub „mające swoją przyczynę w działalności przedsiębiorstwa”, odróżniane od „kosztów osobistych bądź zbędnych”32. Doktryna, reprezentowana m.in. przez H. Litwińczuk ${ }^{33}$ i A. Mariańskiego $^{34}$, opiera się w tym względzie także na badaniach prawnoporównawczych. H. Litwińczuk wskazuje: „ustawodawca niemiecki użył sformułowania, że kosztami uzyskania przychodów są takie wydatki, które mają swoją przyczynę w działalności przedsiębiorstwa (niem. Betriebsausgaben sind die Aufwendungen, die durch den Betrieb veranlasst sind). Istotne znaczenie

31 Zob. ex multis: M. Wilk, Komentarz... i powołana tam literatura; B. Brzeziński, Wyrok..., s. 556.

32 A. Mariański, Brak podstaw do stosowania cywilnoprawnego pojęcia związku przyczynowo-skutkowego jako przesłanki uznania kosztu podatkowego, „Przegląd Podatkowy” 2006, nr 6, s. 13-17.

${ }^{33}$ H. Litwińczuk, Pojęcie kosztów uzyskania przychodów, [w:] Prawo podatkowe przedsiębiorców, red. H. Litwińczuk, wyd. 9, Warszawa 2017, LEX/el.

${ }^{34}$ A. Mariański, Brak podstaw..., s. 13-17; A. Mariański, Nowa koncepcja normatywna kosztów uzyskania przychodów, [w:] Systemowa reforma podatków dochodowych, red. W. Nykiel, B. Brzeziński, I. Kordjak, Warszawa 2009, s. 22-26. Zob. też W. Dmoch, Komentarz...; M. Wilk, Komentarz...; M. Kondej, Jeszcze o koszcie..., s. 96 . Z kolei M. Ślifirczyk widzi kryterium związku z prowadzoną przez podatnika działalnością jako instrument pomocniczy, ułatwiający ustalenie wniosku przyczynowego - „[t]raktowanie takiego wymagania jako równorzędnej wobec związku przyczynowego przesłanki zaliczenia kosztu do kosztów uzyskania przychodów wydaje się niezasadne” (M. Ślifirczyk, Komentarz...). 
ma jedynie rozgraniczenie wydatków na cele przedsiębiorstwa i na cele prywatne. [...] W doktrynie francuskiej można się spotkać z określeniem, że kosztami uzyskania przychodu są wydatki, które są poniesione $\mathrm{w}$ interesie przedsiębiorstwa (fr. une charge n'est déductible fiscalement que dans la mesure où elle correspond à l'intérêt de l'entreprise). Nie podlegają zatem odliczeniu wydatki na cele osobiste ani wydatki, które zostały poniesione $\mathrm{w}$ interesie osoby zarządzającej przedsiębiorstwem lub osoby trzeciej. W ustawodawstwie podatkowym brytyjskim występuje natomiast warunek poniesienia wydatku w celu działalności zarobkowej (ang. for the purpose of the trade)" 35 . Przekład formuły z art. 15 ust. 1 u.p.d.o.p. na związek kosztu $\mathrm{z}$ działalnością gospodarczą przewija się także w orzecznictwie sądowym ${ }^{36}$.

Dość oczywiste (i wyartykułowane expressis verbis przez większość wymienionych autorów) jest spostrzeżenie, że brzmienie polskiego przepisu jest inne niż wyrażone w jego zagranicznych odpowiednikach i niż postulowane przez parafrazę. Dlatego sądy administracyjne stoją nierzadko na stanowisku wyrażonym w wyroku NSA z dnia 20 marca 2018 r., sygn. II FSK 695/16: „,[n]ie wszystkie [...] wydatki związane z działalnością gospodarczą podatnika, nawet gdy są racjonalnie i ekonomicznie uzasadnione, stanowią koszty uzyskania przychodów. Pogląd przeciwny, zgodnie z którym do kosztów podatkowych zalicza się wszelkie koszty związane z prowadzoną działalnością gospodarczą [...], jest zbyt daleko idący i abstrahuje od wskazanego w art. 15 ust. 1 u.p.d.o.p. celu poniesienia kosztu. $\mathrm{W}$ rezultacie nie znajduje oparcia w treści tego przepisu. Uprawnione jest bowiem przyjęcie założenia, że gdyby zamiarem ustawodawcy było uznanie za koszty uzyskania przychodów wszelkich kosztów ponoszonych przez podatnika w ramach działalności gospodarczej, nadałby temu przepisowi takie właśnie brzmienie" ${ }^{37}$. Orzecznictwo nie jest więc jednolite - w konsekwencji wykładnia językowa (rozumiana jako ukształtowany społecznie pogląd o treści przepisu) nie wskazuje jednoznacznie na konieczność parafrazy i nie zobowiązuje do jej przyjęcia.

Co także ważne, potencjalny wpływ na możliwość zaliczenia wydatku (kosztu) do kosztów podatkowych oraz na swobodę działania organów

${ }^{35}$ H. Litwińczuk, Pojęcie kosztów...

36 Zob. np. wyroki NSA: z dnia 4 marca 2020 r., sygn. II FSK 1550/19; z dnia 15 stycznia 2020 r., sygn. II FSK 477/18; z dnia 24 stycznia 2019 r., sygn. II FSK 192/17.

37 Zob. także wyroki NSA: z dnia 20 września 2018 r., sygn. II FSK 2442/16; z dnia 30 maja 2018 r., sygn. II FSK 1360/16; z dnia 17 grudnia 2015 r., sygn. II FSK 2806/13. 
podatkowych (sięgającą dowolności), jaki wywarłoby zastąpienie kryterium celu kryteriami alternatywnymi (takimi jak kryterium związku z działalnością gospodarczą itd.), jest również niejednorodny. Wprawdzie manewr taki usunąłby kontrowersje dotyczące „kosztowości” pewnych wydatków nieuwieńczonych przychodem, otworzyłby jednak inne potencjalne pola sporów. Jego przyjęcie kreuje nowe obszary ryzyka dowolności działań organów podatkowych. Odwołując się do wcześniejszego ustalenia o subiektywno-obiektywnym charakterze kryterium celu, można stwierdzić, że oderwanie aspektu subiektywnego kryterium to zubaża. Ogranicza kryterium do strony obiektywnej - a w jej ramach „związek z działalnością gospodarczą" czy „interes przedsiębiorstwa” to formuły, których zastosowanie w konkretnych okolicznościach sprawy podatkowej może być trudne i sporne.

Ogólnie, wymienione dwa aspekty kryterium celu pozostają z sobą $\mathrm{w}$ układzie, w ramach którego każdemu $\mathrm{z}$ nich może być przypisana różna waga. Różną wagę przypisują im także poszczególni przedstawiciele doktryny $^{38}$. Eliminacja „strony subiektywnej” niekoniecznie prowadzi do szerszej ochrony podatnika czy lepszej realizacji założeń podatku dochodowego (por. także dalsze rozważania). W tej „grze przesłanek” przedstawiciele doktryny podróżują między Scyllą a Charybdą - zarówno aspekt subiektywny, jak i obiektywny rodzą ryzyko niejasności, kontrowersji, sporów. Zależy nam na tym, by obiektywna strona kryterium celu nie przeważała i nie kreowała ryzyka dowolności w działaniu organów podatkowych, oceniających tzw. racjonalność oczekiwania podatnika, że rozpatrywany wydatek przyczyni się do osiągnięcia przychodów podatkowych. Dlatego ciężar przenosimy (w większym lub mniejszym stopniu - zależnie od autora) na stronę subiektywną ${ }^{39}$. W takim jednak razie nie możemy zbanalizować

38 Przykładowo K. Gil we wcześniej powołanej publikacji proponuje, by formułę $\mathrm{z}$ art. 15 ust. 1 u.p.d.o.p. rozumieć następująco: „każdy koszt (wydatek), do którego zobowiązany jest podatnik, jest kosztem uzyskania przychodu, jeżeli w subiektywnym zamiarze tego podatnika może on doprowadzić do powstania przychodu, jego zachowania lub zabezpieczenia” - sprzeciwia się zaś „obiektywnej i racjonalnej weryfikacji zasadności ponoszonych kosztów” przez organ podatkowy („ogołaca” zatem przesłankę celu z aspektu obiektywnego) (K. Gil, Zasada ponoszenia kosztów..., s. 23-24).

39 Są i inne troski - M. Kondej za niewłaściwe uznaje poprzestawanie na subiektywnej „stronie” kryterium celu, gdyż jego zdaniem naruszałoby to zasadę sprawiedliwości i równości podatkowej - podatnicy znajdujący się w obiektywnie porównywalnej sytuacji zależnie od swojej intencji byliby uprawnieni do rozpoznania kosztu lub nie (M. Kondej, Jeszcze o koszcie..., s. 101). Nie jest oczywiste, jak sądzę, że podatnicy tacy rzeczywiście znajdują się w sytuacji porównywalnej. 
aspektu subiektywnego kryterium celu przez uznawanie tego kryterium za zawsze spełnione (bądź takie, którego spełnienie jest niekonieczne albo zagwarantowane przez samą deklarację podatnika). Trzeba uważać, by balansując między kryteriami, nie wyzuć rozpatrywanego przepisu z treści: nie przyjąć wykładni, w której ani aspekt subiektywny, ani obiektywny nie narzucają żadnego ograniczenia i nie pozwalają dociec, jakiej właściwie natury ma być związek między kosztem a przychodem ${ }^{40}$.

Zamiana kryterium celu $\mathrm{w}$ aspekcie subiektywnym na alternatywne formuły nie powoduje zmiany konkluzji co do kosztowości wydatku $\mathrm{w}$ celu poniesienia straty podatkowej. Koszt poniesiony w celu poniesienia straty podatkowej nie jest poniesiony „w interesie przedsiębiorstwa”, nie ma też „swojej przyczyny w działalności przedsiębiorstwa”. W interesie przedsiębiorstwa, który za prawowity uznaje ustawodawca podatkowy (i uznawał w czasie przed wprowadzeniem GAAR), nie leży per se minimalizacja zobowiązania podatkowego ${ }^{41}$. Pogląd ten bynajmniej nie zakłada uogólnionego negatywnego nastawienia ustawodawcy do „celu podatkowego” czy też „korzyści podatkowej” (ich pejoratywnej oceny). Jest skromniejszy, oparty na przesłankach ściśle normatywnych, czerpanych z samego tekstu ustawy. Za znamienne należy mianowicie uznać sformułowanie przepisów u.p.d.o.p., traktujących jako rozłącznie uzasadnione przyczyny ekonomiczne oraz podatkowy motyw działania (obecnie art. 11a ust. 4, art. 12 ust. 14 i 14b, art. 14 ust. 1 , art. 22 c ust. 2 , art. 24 a ust. 16, art. 24 b ust. 18, art. 24 f ust. 9 u.p.d.o.p.). Zgodnie z ich brzmieniem cel gospodarczy wyklucza się z celem podatkowym - co oznacza, że z punktu widzenia ustawy minimalizacja zobowiązania podatkowego nie leży w obrębie działalności gospodarczej ${ }^{42}$.

40 Teoretycznie jest natomiast możliwe, by stronę subiektywną i obiektywną kryterium celu traktować jako alternatywę nierozłączną, tj. by uznać hipotezę art. 15 ust. 1 u.p.d.o.p. za spełnioną, gdy jest spełniony co najmniej jeden z dwóch warunków: wydatek (koszt) był poniesiony w celu uzyskania przychodów (aspekt subiektywny) lub wydatek (koszt) przyczynił się do uzyskania przychodów podatkowych (aspekt obiektywny).

41 Żartobliwa formuła głosi: „there's no business reason better than tax reason”. Ustawodawca podatkowy nie zdradza się jednak z aprobatą dla tego poglądu. Przewrotny argument, że minimalizacja obciążeń podatkowych pozostawia więcej środków finansowych na inwestycje, których dokonywanie leży w interesie przedsiębiorstwa, jest ekstrawagancki, lecz - jako wsparcie dla możliwości zaliczenia wydatku (kosztu) do kosztów uzyskania przychodów na podstawie stosowania art. 15 ust. 1 u.p.d.o.p. - nietrafny.

42 Dodatkową trudnością, jaką rodzi przekład formuły ustawowej na kryterium poniesienia wydatku w interesie przedsiębiorstwa, jest zasada źródłowości w podatkach dochodowych (od 2018 r. także na gruncie u.p.d.o.p.). Kryterium celu daje się wprost 
Kontekst językowy nie jest jedynym, który należy wziąć pod uwagę, ustalając treść normatywną art. 15 ust. 1 u.p.d.o.p. Trzeba zmierzyć się z podstawową wątpliwością: jak dyskutowane wyżej rozumienie tego przepisu, akcentujące subiektywną stronę kryterium celu, ma się do założeń konstrukcyjnych ustaw o podatkach dochodowych. Podstawowym założeniem konstrukcyjnym tej ustawy, pozostającym w związku z jej głównym celem, jest to, że przedmiotem opodatkowania ma być dochód, rozumiany jako przyrost majątku w jednostce czasu (okresie rozliczeniowym). Niezgodne z tym założeniem i celem, odpowiednio, jest opodatkowanie nie dochodu, lecz przychodu - do czego dochodzi wtedy, gdy organ podatkowy odmawia uznania rzeczywiście poniesionego wydatku za koszt uzyskania przychodów.

Argumentację idącą $\mathrm{w}$ tę stronę przedstawili m.in. M. Ślifirczyk i M. Kondej. Ten pierwszy wskazuje, że „[k]onstrukcja kosztów uzyskania przychodów, obok konstrukcji przychodu, stanowi podstawowy element polskiego podatku dochodowego. Tylko prawidłowe ustawowe ujęcie tej materii pozwala na zachowanie istoty podatku dochodowego. [...] Nie można także traktować kosztów uzyskania przychodu jako rodzaju ulgi podatkowej, jest to bowiem podstawowy element konstrukcyjny podatku służący do zdefiniowania podstawy opodatkowania"43. M. Kondej wywodzi, że racjonalność ekonomiczna wydatku, rozumiana jako „uzasadnione oczekiwanie podatnika, że jego poniesienie doprowadzi do osiągnięcia przychodu w kwocie przekraczającej wartość podatku", nie stanowi warunku zaliczenia wydatku do kosztów uzyskania przychodów. Postawienie takiego warunku "naruszałoby istotę podatku dochodowego" 44 - a zarazem (wolno dodać) zasady konstrukcyjne ustawy, do których należy to, że opodatkowany ma być dochód, nie zaś przychód. Z kolei m.in. P. Borszowski określa art. 15 ust. 1 u.p.d.o.p. mianem klauzuli generalnej, której

odnieść do przychodu z danego źródła, „interes przedsiębiorstwa” może dotyczyć obu źródeł (kryterium po parafrazie nie rozstrzyga, do którego ze źródeł przypisać rozpatrywany koszt).

${ }^{43}$ M. Ślifirczyk, Komentarz... Podobnie W. Morawski, Ulgi i zwolnienia $w$ prawie podatkowym, Gdańsk 2003, s. 51.

${ }^{44}$ M. Kondej, Jeszcze o koszcie..., s. 93. 
zastosowanie przez ustawodawcę ma na celu dostosowanie poziomu opodatkowania do rzeczywistości gospodarczej ${ }^{45}$.

Podzielając co do zasady te tezy (a także ich założenie metodologiczne, zgodnie z którym tekst ustawy podatkowej należy odczytywać w zgodzie $z$ konstrukcją danego podatku), pragnę zwrócić uwagę na kwestie, które ostatecznie mogą przesądzić o wyłączeniu z kosztów podatkowych wydatku (kosztu) niespełniającego kryterium celu.

Koszt uzyskania przychodów na równi z przychodem podatkowym stanowi element konstrukcyjny podatku dochodowego. Co do zasady opodatkowaniu podatkiem dochodowym podlega dochód, jako dodatnia różnica między wartością przychodów podatkowych (z danego źródła) nad kosztami ich uzyskania. Opodatkowanie podatkiem dochodowym powinno być adekwatne do osiągniętego dochodu, przez adekwatne obciążenie podatkowe rozumie się bowiem obciążenie odpowiednie do założeń konstrukcyjnych danego podatku ${ }^{46}$.

W dyskusji na temat przedmiotu podatku dochodowego, jako determinującego wykładnię art. 15 ust. 1 u.p.d.o.p. zaznacza się jednak dwoistość. Dochód, którego dotyczy ustawa, a przez to i ten argument, to dochód w znaczeniu prawnym lub dochód w znaczeniu ekonomicznym. Nie są to pojęcia od siebie oderwane; dochód w znaczeniu prawnym (wyznaczonym przepisami ustaw o podatku dochodowym) jest prawnym konstruktem, przez który co do zasady ma zostać „uchwycony” dochód w znaczeniu ekonomicznym. Z kolei dochód w znaczeniu ekonomicznym jest „zmediatyzowany”, zapośredniczony w znaczeniu prawnym - to przez pryzmat tego ostatniego widziany jest ten pierwszy. Pojęcia te nie są jednak także tożsame. Poza i ponad wszelkimi różnicami wynikającymi z treści samej ustawy (która określa zwłaszcza, co przychodem i dochodem nie jest, i określa, kiedy przychód i dochód powstaje) różnica fundamentalna

45 P. Borszowski, Normatywne określenie..., s. 366. Uznanie art. 15 ust. 1 u.p.d.o.p. za klauzulę generalną implikuje, że przepis ten zawiera odesłanie pozasystemowe (pozaprawne), w tym przypadku do rzeczywistości gospodarczej (por. A. Choduń, Rozdział I.1.3, [w:] A. Choduń, A. Gomułowicz, A. Skoczylas, Klauzule generalne i zwroty niedookreślone w prawie podatkowym $i$ administracyjnym. Wybrane zagadnienia teoretyczne i orzecznicze, Warszawa 2013, LEX/el.). Nie jestem pewna, czy to prawda; wydaje się, że takim odesłaniem operuje raczej przepis „definiujący” dochód (art. 7 ust. 1 i 2 u.p.d.o.p.).

46 Por. m.in. B. Brzeziński, Wykładnia prawa podatkowego, Gdańsk 2013, s. 164; B. Brzeziński, H. Filipczyk, Dyrektywa wykładni gospodarczej jako postulat wykładni operatywnej prawa podatkowego (cz. I), „Prawo i Podatki” 2010, nr 7, s. 2 (w kontekście tzw. wykładni gospodarczej). 
dotyczy relacji do przepisów. Prawne pojęcie dochodu wynika z przepisów, ekonomiczne pojęcie dochodu wynika z rzeczywistości ekonomicznej (pozanormatywnej) ${ }^{47}$.

Dochód w znaczeniu ekonomicznym to byt pozaprawny - rzeczywisty przyrost majątku netto (czysty przyrost majątku). Przyjmując (co moim zdaniem należy uczynić), że założeniem konstrukcyjnym ustaw o podatku dochodowym jest ostatecznie opodatkowanie dochodu w znaczeniu ekonomicznym, należy odrzucić taką wykładnię i taki sposób zastosowania art. 15 ust. 1 u.p.d.o.p., które prowadziłyby do opodatkowania nieadekwatnego do rzeczywiście osiągniętego przez podatnika dochodu w tym znaczeniu (wyższego niż ten dochód). Moim zdaniem podatnik może wskazywać - w charakterze argumentu za zaliczeniem kwestionowanego przez organ podatkowy wydatku do kosztów podatkowych - na nieadekwatność podatku obliczonego po wyłączeniu kwestionowanego wydatku dochodowego do rzeczywiście osiągniętego dochodu. Zasady konstrukcyjne ustawy o podatku dochodowym, do których należy opodatkowanie dochodu (a nie przychodu), należy przedłożyć nad brzmienie jej przepisów - przełamując w tym przypadku na korzyść podatnika treść art. 15 ust. 1 u.p.d.o.p.

Ta droga argumentacyjna w praktyce może się nie sprawdzić w przypadku struktur abuzywnych. Jest tak nie dlatego, że miałyby one zostać a limine wyłączone z pola zastosowania argumentu (do takiego wyłączenia nie ma normatywnych podstaw), lecz dlatego, że nie znajdą się w tym polu ze względu na swoją charakterystykę i relację do dochodu. Korzyść podatkowa osiągana przez unikanie opodatkowania w podatku dochodowym polega na opodatkowaniu nieadekwatnym do rzeczywiście osiągniętego dochodu, gdyż od tego dochodu niższym. $Z$ tej przyczyny podatnikowi nie uda się obronić tym argumentem przed wyłączeniem $z$ kosztów podatkowych wydatku poniesionego w celu abuzywnym. Nie uda mu się bowiem wykazać, że odczytanie art. 15 ust. 1 u.p.d.o.p. prowadzi do opodatkowania nieadekwatnego do dochodu, gdyż do opodatkowania wyższego

${ }^{47} \mathrm{~W}$ tej sprawie zob. K. Holmes, The Concept of Income: A Multidisciplinary Analysis, Amsterdam 2001, rozdz. 2; B. Brzeziński, Perypetie podatku dochodowego z sadownictwem administracyjnym, [w:] Wykładnia i stosowanie prawa podatkowego. Węzłowe problemy, red. B. Brzeziński, Warszawa 2013; R. Zieliński, Pojęcie dochodu podatkowego, „Państwo i Prawo" 2009, nr 10, s. 48-56; L. Kleczkowski, Pojęcie dochodu w polskim prawie podatkowym, „Kwartalnik Prawa Podatkowego” 2009, nr 3-4, s. 56-60; H. Filipczyk, Refleksje o przedmiocie podatku dochodowego, „Kwartalnik Prawa Podatkowego” 2015, nr 2, s. 39-55. 
niż wynikające z zastosowania wobec rzeczywiście osiągniętego dochodu stawki ustawowej ${ }^{48}$.

Przekładając te uwagi na użyty wcześniej przykład wydatku poniesionego w celu poniesienia straty podatkowej - celem działania podatnika jest wykorzystanie tej straty do obniżenia dochodu podatkowego. W rezultacie tego działania jego dochód w znaczeniu ekonomicznym ma (w całości lub w części) nie podlegać opodatkowaniu. Zastosowanie wobec wydatku (kosztu) art. 15 ust. 1 u.p.d.o.p. - poprzez jego wyłączenie z rachunku kosztów podatkowych - powoduje, że strata podatkowa nie wystąpi. To z kolei sprawi, że dochód w znaczeniu ekonomicznym będzie podlegać opodatkowaniu podatkiem dochodowym - co nie jest przeciwne, lecz wprost zgodne z założeniem konstrukcyjnym ustawy o podatku dochodowym.

Przejdźmy z kolei do dochodu w znaczeniu prawnym. Jest on konstruktem regulacji prawnej, w tym art. 15 ust. 1 u.p.d.o.p. Powoduje to, że trudno powoływać się na dochód w znaczeniu prawnym w celu określenia treści art. 15 ust. 1. Taka argumentacja byłaby kolista. W determinacji dochodu w znaczeniu prawnym, tj. określeniu, co tym dochodem jest, ma bowiem udział sam ten przepis. W określenie, co jest takim dochodem (kiedy dochód powstaje i w jakiej wysokości), uwikłana jest treść art. 15 ust. 1 u.p.d.o.p.

Zarazem ponieważ oba pojęcia dochodu: ekonomiczne i prawne, choć nietożsame, nie są jednak także rozłączne (dochód $\mathrm{w}$ znaczeniu prawnym to pryzmat, przez który widziany jest dochód w znaczeniu ekonomicznym), można sformułować dodatkową tezę: o konieczności przyjęcia domniemania kosztowości podatku ${ }^{49}$. Być może zatem ostatecznie to nie tylko podatnik może posługiwać się wyżej wskazanym argumentem, lecz również organ podatkowy z własnej inicjatywy powinien badać, czy przez wyłączenie wydatku (kosztu) z rachunku podatkowego nie dochodzi do zniekształcenia wyniku podatkowego - tak, że przedmiot opodatkowania rozmija się z założeniem opodatkowania rzeczywistego dochodu (przyrostu

${ }^{48}$ I odwrotnie - jeżeli podatnikowi uda się to wykazać, będzie to oznaczać, że jego czynności nie stanowiły unikania opodatkowania podatkiem dochodowym.

49 Zgadzam się pod tym względem z: M. Kondej, Jeszcze o koszcie..., s. 96. Warto byłoby natomiast rozważyć, jak to domniemanie ma się do domniemania poprawności złożonej przez podatnika deklaracji podatkowej, opartego na art. $21 \$ 2$ o.p., a także do czego konkretnie zobowiązuje ono organ podatkowy (i co daje podatnikowi). Czy nie okaże się, że domniemanie to ostatecznie niewiele wnosi (nadaje tylko pewne dodatkowe „Zabarwienie” argumentacji, czy też ma siłę jedynie perswazyjną)? 
majątku netto $)^{50}$. Takie zastosowanie nie byłoby, rzecz jasna, równoważne traktowaniu analizowanego przepisu jako klauzuli antyabuzywnej. Spełnienie kryterium celu uprawnia i zobowiązuje do włączenia wydatku (kosztu) do kosztów uzyskania przychodów nawet w razie nieadekwatności wyniku podatkowego do rzeczywistości gospodarczej.

\section{OPŁATY LICENCYJNE ZA KORZYSTANIE Z UPRZEDNIO ZBYTEGO ZNAKU} TOWAROWEGO A POPRAWNE ZASTOSOWANIE ART. 15 UST. 1 U.P.D.O.P.

Po powyższej dyskusji warto powrócić na moment do przedmiotu orzekania w sprawach, w których zostały wydane wymienione na wstępie wyroki WSA w Opolu i WSA w Lublinie. Opowiadając się za kryterium celu w ujęciu subiektywnym, trzeba zarazem uznać, że zastosowanie tego kryterium do spraw rozstrzyganych przez te sądy przynosi rezultat odmienny od tego, który przyjęły działające w tych sprawach organy podatkowe. Podatnicy ponoszący wydatki z tytułu opłat licencyjnych za używanie znaku towarowego mieli na celu uzyskiwanie przychodów ze sprzedaży towarów opatrzonych tymi znakami - był to cel poniesienia tych wydatków (cel samoistny). Dlatego bez wątpienia byli oni uprawnieni do zaliczenia wydatków do kosztów uzyskania przychodów. Ostatecznie słuszna jest krytyka wyroków sądów z Opola i Lublina przedstawiona w powołanych na wstępie publikacjach.

Ten przykład ukazuje wadliwość argumentacji organów podatkowych, zbudowanej na elementach pozbawionych znaczenia z punktu widzenia treści normatywnej rozpatrywanego przepisu. Po pierwsze, przepis ten nie pozwala na kwestionowanie czynności ważnie i skutecznie dokonanych z punktu widzenia prawa prywatnego (cywilnego, handlowego). Po drugie, przepis nie pozwala na analizę wykraczającą poza czynność polegającą na

50 „Ustalenie znaczenia pojęcia «koszty» polega zatem przede wszystkim na ustaleniu jego znaczenia według konwencji przyjętej przez ustawodawcę podatkowego. Ustawodawca nie ma jednak pełnej swobody w zakresie kształtowania pojęcia kosztów uzyskania przychodów. Wydaje się, że powinien on uwzględniać logikę konstrukcji podatku dochodowego. Logika ta polega na obciążeniu podatkiem dochodu podatnika, a więc pewnej nadwyżki, jaka pozostaje w jego dyspozycji [...]. Gwarancją zachowania takiego charakteru jest utrzymanie związku między prawnym pojęciem kosztu a kosztem w rozumieniu ekonomicznym. Związek ten nie musi mieć bezwzględnego charakteru, powinien być jednak zachowany. Modyfikacje pojęcia kosztu wynikające z konieczności zapewnienia efektywności i wewnętrznej logiki konstrukcji podatkowych prowadzą do wytworzenia konstrukcji kosztów uzyskania przychodów" (M. Ślifirczyk, Komentarz...). 
poniesieniu wydatku (kosztu) - obejmującą czynności wobec niej uprzednie. Tym samym nie pozwala również na analizę wykraczającą poza moment poniesienia wydatku (kosztu). Stan rzeczy istniejący w momencie jego ponoszenia należy przyjąć jako dany.

W konsekwencji - na co w powołanych na wstępie publikacjach słusznie zwracają uwagę m.in. K. Gil i J. Zawiejska-Rataj oraz W. Nykiel i M. Wilk - nie ma znaczenia prawnego charakterystyka czynności dokonanych przez podatnika wcześniej (ich cel, zasadność, racjonalność ekonomiczna itd.), tj. przed poniesieniem wydatku (w tym przypadku: bez znaczenia jest fakt wyzbycia się przez podatnika własności znaku towarowego, za korzystanie z którego następnie podatnik ponosi opłaty licencyjne).

Przykład ten ukazuje ponadto, że - także w ujęciu tu postulowanym - art. 15 ust. 1 u.p.d.o.p. w ograniczonym stopniu pozwalał i pozwala na zwalczanie unikania opodatkowania. Jego zastosowanie lege artis wobec wydatków (kosztów), których samoistnym celem nie było uzyskanie przychodów podatkowych, jest jednak możliwe (dopuszczalne, prawnie legitymowane) i może dać efekt antyabuzywny.

9. WNIOSKI

Rozważania prowadzą do następujących wniosków.

Przepis art. 15 ust. 1 u.p.d.o.p. różni się normatywną treścią od klauzul antyabuzywnych, w tym od klauzuli ogólnej przeciwko unikaniu opodatkowania (art. 119a i n. o.p.) - należy w tym zakresie podzielić pogląd wyrażony w dotychczasowych, licznych publikacjach.

Przepis ten uzasadnia jednak odmowę zaliczenia do kosztów uzyskania przychodów wydatku (kosztu) niespełniającego ustawowego kryterium celu: takiego, który nie został poniesiony „w celu osiągnięcia przychodów [...] lub w celu zachowania albo zabezpieczenia źródła przychodów”. Dotyczy to wydatków, dla których osiągnięcie przychodów itd. nie było samoistnym celem; w szczególności wydatków (kosztów) poczynionych w celu poniesienia straty podatkowej. Odmowa ich zaliczenia do kosztów uzyskania przychodów może doprowadzić do zniweczenia skutków podatkowych unikania opodatkowania.

Wykładnia stojąca u podstaw tego poglądu jest oparta na brzmieniu art. 15 ust. 1 u.p.d.o.p. Wykładnia ta, jak się wydaje, odbiega od dominującego poglądu doktryny; w pewnej mierze znajduje oparcie w orzecznictwie sądowym. Otwarte należy pozostawić pytanie o jej poprawność z punktu widzenia wykładni językowej sensu largo, opartej na konwencji rozumienia 
przepisów przez wspólnotę interpretacyjną. Niewątpliwie jednak organ podatkowy, który powołuje taką wykładnię, nie działa w sposób niedorzeczny (może powołać sensowne argumenty, w tym argument $\mathrm{z}$ treści językowej przepisu sensu stricto).

Wykładnia ta jest natomiast niesprzeczna z założeniami konstrukcyjnymi u.p.d.o.p. - przy zastrzeżeniu, że odmowa uznania wydatku (kosztu) za koszt uzyskania przychodów następuje po sprawdzeniu, czy nie doprowadzi ona do nieadekwatności opodatkowania podatkiem dochodowym do rzeczywiście osiągniętego dochodu (dochodu w znaczeniu ekonomicznym).

W zakresie zagadnienia, które było przedmiotem orzekania WSA w Opolu i WSA w Lublinie, postulowana wykładnia art. 15 ust. 1 u.p.d.o.p., oparta na kryterium celu, nie uzasadnia odmowy zaliczenia do kosztów uzyskania przychodów wydatków z tytułu opłat licencyjnych za korzystanie ze znaku towarowego, uprzednio przeniesionego na podmiot powiązany. Okazuje to granice dopuszczalności stosowania art. 15 ust. 1 u.p.d.o.p. do zwalczania (niweczenia) unikania opodatkowania, a tym samym granice jego skuteczności w tej roli.

\section{BIBLIOGRAFIA}

Arystoteles, Etyka nikomachejska, tłum. D. Gromska, Warszawa 2007.

Bołd J., Komentarz do art. 15, [w:] Podatek dochodowy od osób prawnych. Komentarz, red.

K. Gil, A. Obońska, A. Wacławczyk, A. Walter, wyd. 3, Warszawa 2020.

Borszowski P., Normatywne określenie „kosztów podatkowych z działalności gospodarczej” - zagadnienie elastyczności, [w:] Finanse publiczne i prawo finansowe - realia i perspektywy zmian, red. L. Etel, M. Tyniewicki, Białystok 2012.

Brzeziński B., Perypetie podatku dochodowego z sq̨ownictwem administracyjnym, [w:] Wykładnia i stosowanie prawa podatkowego. Węzłowe problemy, red. B. Brzeziński, Warszawa 2013.

Brzeziński B., Wykładnia prawa podatkowego, Gdańsk 2013.

Brzeziński B., Wyrok Wojewódzkiego Sądu Administracyjnego w Lublinie z dnia 22 stycznia 2019 r. (I SA/Lu 48/19) - glosa, „Przegląd Orzecznictwa Podatkowego” 2019, nr 4.

Brzeziński B., Filipczyk H., Dyrektywa wykładni gospodarczej jako postulat wykładni operatywnej prawa podatkowego (cz. I), „Prawo i Podatki” 2010, nr 7.

Choduń A., Rozdział I.1.3, [w:] A. Choduń, A. Gomułowicz, A. Skoczylas, Klauzule generalne i zwroty niedookreślone w prawie podatkowym i administracyjnym. Wybrane zagadnienia teoretyczne i orzecznicze, Warszawa 2013.

Dmoch W., Komentarz do art. 15, [w:] W. Dmoch, Podatek dochodowy od osób prawnych. Komentarz, Warszawa 2020.

Filipczyk H., Jeszcze raz o kosztach uzyskania przychodów - cztery mity, „Prawo i Podatki” 2009, nr 12. 
Filipczyk H., Refleksje o przedmiocie podatku dochodowego, „Kwartalnik Prawa Podatkowego" 2015, nr 2.

Filipczyk H., Tax Avoidance and Rationality of Law, Warszawa 2017.

Gil K., Zasada ponoszenia kosztów w celu uzyskania przychodów w świetle reguł wykładni przepisów prawa podatkowego, „Monitor Podatkowy” 2010, nr 7.

Gil K., Zawiejska-Rataj J., Próba wskrzeszenia klauzuli obejścia prawa podatkowego - czyli czy art. 15 ust. 1 PDOPrU pozwala na wyłaczenie z kosztów podatkowych wydatków wynikajacych z czynności dokonanych w celu uzyskania korzyści podatkowej. Glosa do wyroków WSA w Opolu I SA/OP 86/19 oraz WSA w Lublinie I SA/Lu 48/19, „Monitor Podatkowy" 2020, nr 3.

Gomułowicz A., Prawna formuła kosztu podatkowego, Warszawa 2016.

Gruszczyński B., Cel osiąnięcia przychodów, „Glosa” 2003, nr 2.

Holmes K., The Concept of Income: A Multidisciplinary Analysis, Amsterdam 2001.

Karwat P., Klauzula ogólna a przepisy szczególne przeciwdziałające unikaniu opodatkowania, „Przegląd Podatkowy” 2016, nr 12.

Kleczkowski L., Pojęcie dochodu w polskim prawie podatkowym, „Kwartalnik Prawa Podatkowego" 2009, nr 3-4.

Kondej M., Jeszcze o koszcie jako wydatku związanym z przychodami. Racjonalność działania podatnika jako przesłanka rozpoznania kosztu podatkowego, „Kwartalnik Prawa Podatkowego" 2018, nr 4.

Kondej M., Ustawowa definicja kosztu uzyskania przychodu jako quasi-klauzula przeciwko unikaniu opodatkowania, „Monitor Podatkowy” 2019, nr 8.

Litwińczuk H., Pojęcie kosztów uzyskania przychodów, [w:] Prawo podatkowe przedsiębiorców, red. H. Litwińczuk, wyd. 9, Warszawa 2017.

Litwińczuk H., Regulacje o cenach transferowych a ogólna norma przeciwko unikaniu opodatkowania, „Przegląd Podatkowy” 2018, nr 10.

Małecki P., Mazurkiewicz M., Komentarz do art. 15, [w:] P. Małecki, M. Mazurkiewicz, CIT. Komentarz. Podatki i rachunkowość, wyd. 10, Warszawa 2019.

Mariański A., Brak podstaw do stosowania cywilnoprawnego pojęcia związku przyczynowo-skutkowego jako przesłanki uznania kosztu podatkowego, „Przegląd Podatkowy” 2006, nr 6.

Mariański A., Nowa koncepcja normatywna kosztów uzyskania przychodów, [w:] Systemowa reforma podatków dochodowych, red. W. Nykiel, B. Brzeziński, I. Kordjak, Warszawa 2009.

Morawski W., Ulgi i zwolnienia w prawie podatkowym, Gdańsk 2003.

Nykiel W., Wilk M., Niedopuszczalność wykorzystania art. 15 ust. 1 u.p.d.o.p. jako klauzuli przeciwko unikaniu opodatkowania. Glosa do wyroku WSA z dnia 19 sierpnia 2019 r., I SA/Op 86/19, „Przegląd Podatkowy” 2020, nr 2.

Ślifirczyk M., Komentarz do art. 15, [w:] G. Dźwigała i in., Ustawa o podatku dochodowym od osób prawnych. Komentarz, wyd. 2, Warszawa 2009.

Wilk M., Komentarz do art. 15, [w:] A. Krajewska i in., Podatek dochodowy od osób prawnych. Komentarz, wyd. 4, Warszawa 2016.

Zieliński R., Pojęcie dochodu podatkowego, „Państwo i Prawo” 2009, nr 10. 
THE CRITERION OF PURPOSE FOR WHICH AN EXPENSE WAS INCURRED AND TAX DEDUCTIBLE COSTS - NORMATIVE CONTENT

\section{AND ANTI-ABUSIVE IMPLICATIONS (A DISCUSSION)}

Summary. The article argues that under Article 15 Section 1 of the Act of 15 February 1992 on corporate income tax an expense (cost) can be tax deductible only if it meets the criterion of purpose, understood subjectively, i.e. such that obtaining tax revenues or conserving or securing their source was a primary (non-instrumental) purpose of a taxpayer who incurred the expense (cost). This condition is not fulfilled for expenses (costs) incurred with the aim of making tax losses. Consequently, in some cases the application of the provision, by refusal to qualify an expense (cost) as tax deductible, may thwart the taxpayer's attempt to avoid taxation.

Keywords: tax cost, tax deductible cost, tax avoidance, Article 15 Section 1 of the Act of 15 February 1992 on corporate income tax 